\title{
PENGEMBANGAN INTERVENSI PERAWATAN LUKA PADA FOURNIER GANGRENE DENGAN MENGGUNAKAN NEGATIVE PRESSURE WOUND CARE BERDASARKAN COMFORT THEORY
}

\author{
CHINDY MARIA ORIZANI \\ AKADEMI KEPERAWATAN ADI HUSADA \\ chindyorizani@gmail.com
}

\begin{abstract}
ABSTRAK
Fournier's gangrene merupakan fasciitis nekrotikans yang progresif pada daerah penis, skrotum, dan perineum dan memiliki potensi fatal dengan angka mortalitas tinggi dan termasuk dalam kasus kegawatdaruratan bedah dan urologi. Negative Pressure Wound Care merupakan perawatan luka pada pasien dengan Fournier's Gangrene sebelum dilakukan debridemen dan digunakan sebagai metode untuk menurunkan nyeri dan meningkatkan kenyamanan klien. Tujuan dari studi ini adalah untuk melakukan analisis intervensi perawatan luka pada Fournier's gangrene dengan menggunakan Negative Pressure Wound Care berdasar teori Comfort. Pencarian literatur yang relevan, dilakukan dengan mengakses database PubMed, ScienceDirect, dan SAGEPub dibatasi dari Januari 2006 sampai dengan Oktober 2015. Keywords yang digunakan adalah "Fournier's gangrene", "negative pressure wound therapy", "Vacuum-assisted closure", "chronic wound therapy". Negative pressure wound therapy sangat efektif untuk mengontrol drainage luka setelah debridemen, mempermudah granulasi luka dan menurunkan penggunaan kasa/dressing luka dan proses perawatan dapat menimbulkan rasa nyaman bagi klien dibandingkan perawatan lain. Negative pressure wound therapy merupakan aplikasi tindakan keperawatan yang berdasarkan teori comfort yaitu meningkatkan kenyamanan klien dengan menurunkan tingkat nyeri yang dirasakan klien sehingga meningkatkan kualitas hidup klien.
\end{abstract}

Kata kunci: Fournier's gangrene, negative pressure wound therapy, penyembuhan luka

\begin{abstract}
Fournier's gangrene is a progressive necrotizing fasciitis in the area of the penis, scrotum, and perineum and potentially fatal disease with a high mortality rate and included in the case of emergency surgery and urology. Negative Pressure Wound Care is a wound care in patients with Fournier's Gangrene before debridement and used as a method to reduce pain and increase the comfort of the client. The aim of this study was to analyzed the wound care interventions on Fournier gangrene using Negative Pressure Wound Care on the Comfort theory. Search methods relevant literature, performed by accessing the databases PubMed, ScienceDirect, and SAGEPub restricted from January 2006 to October 2015. Keywords used were "Fournier's gangrene", "negative pressure wound therapy", "Vacuum-assisted closure", "chronic wound therapy ". Negative pressure wound therapy is very effective for controlling wound drainage after debridement, wound granulation simplify and reduce the use of gauze / dressing wounds and the treatment process may cause a sense of comfort for the client than other treatments. Negative pressure wound therapy is the application of nursing actions based on the comfort theory which can improve client comfort by lowering the level of pain felt by clients thus improving quality of life for clients.
\end{abstract}

Keywords: Fournier's gangrene, negative pressure wound therapy, wound healing 


\section{PENDAHULUAN}

Fournier's gangrene merupakan fasciitis nekrotikans yang progresif pada daerah penis, skrotum, dan perineum. ${ }^{12}$ Fournier's gangrene termasuk penyakit infeksi yang fatal namun jarang terjadi. Fournier's gangrene pertama kali ditemukan pada tahun 1883 oleh seorang venerologis Prancis Jean Alfred Fournier. Infeksi pada Fournier's gangrene memiliki karakteristik khas, yaitu akan menyebabkan trombosis pada pembuluh darah subkutis yang akan menyebabkan nekrosis kulit di sekitarnya. Fournier's gangrene merupakan penyakit yang memiliki potensi fatal dengan angka mortalitas tinggi dan termasuk dalam kasus kegawatdaruratan bedah dan urologi.

Pada beberapa tahun terakhir kasus insiden Fournier's gangrene cenderung meningkat. Fournier yang pertama kali melaporkan kejadian penyakit ini pada tahun 1883 terhadap 5 pria yang menderita gangrene skrotum, menyebutkan bahwa sebabnya adalah idiopatik. Saat ini penyebab penyakit ini dapat diungkapkan, di antaranya 13-50\% adalah infeksi dari kolorektal dan 17-87\% sumber infeksi dari urogenitalia, sedang yang lain dari trauma lokal atau infeksi kulit di sekitar genitalia. ${ }^{3}$ Kelainan kolorektal yang dilaporkan sering menyebabkan penyakit ini di antaranya adalah abses pada perianal, perirektal, atau isiorektal, dan perforasi karena kanker kolon, instrumentasi, atau divertikulitis. Sumber dari urogenitalia adalah: striktura uretra yang menyebabkan ekstravasasi urine, balanitis, dan instrumentasi uretra. Diabetes mellitus, alkoholisme, higiene skrotum yang kurang baik, serta penurunan imunitas tubuh seperti pada pasien AIDS memudahkan terjadinya penjalaran Fournier's gangrene. Angka mortalitas Fournier's gangrene berkisar dari $7-75 \%$ dengan rerata 20\%. ${ }^{12}$ Berbagai faktor yang mempengaruhi terjadinya mortalitas adalah: usia lanjut, penyakit yang sudah menjalar luas, syok atau sepsis, kultur darah menunjukkan bakteriemia, dan uremia.

Hal ini disebabkan faktor predisposisi dari Fournier's gangrene seperti diabetes mellitus, imunosupresi, dan penyakit hati dan ginjal kronik juga meningkat dalam beberapa tahun ini. ${ }^{10}$ Infeksi pada sebagian besar kasus Fournier's gangrene merupakan gabungan sinergis antara bakteri aerob dan anaerob. Pada awalnya terdapat demam yang dapat berkembang menjadi demam tinggi sampai toksemia, syok, dan delirium. Keadaan lokal pada penis, skrotum dan kulit sekitarnya tampak bengkak, nyeri, teraba hangat, dan eritematous. Jika teraba krepitasi menandakan adanya infeksi kuman pembentuk gas, di antaranya adalah Clostridium spp. Pada fase lanjut, terjadi gangrene dengan nekrosis luas, plak berwarna hitam dan hijau, dan sekret sangat berbau. Mikroorganisme penyebab infeksi seringkali tidak hanya satu macam, melainkan merupakan infeksi polimikroba dari enterik gram negatif, gram positif Stafilokokus atau Streptokokus, dan bakteri anerobik (Clostridium spp). E coli, Bakteroides, Klebsiella spp, Proteus spp, Pseudomonas spp, dan Enterokoki disebut sebagai bakteri yang paling sering menyebabkan infeksi ini.

Dasar penanganan Fournier's gangrene adalah dengan stabilisasi hemodinamik, terapi antibiotik sistemik, dan surgical debridement. Prinsip terapi pada gangrene Fournier adalah terapi suportif memperbaiki keadaan umum pasien, pemberian antibiotika, dan debridement dengan membuang jaringan nekrosis. Antibiotika yang dipilih adalah yang sesuai dengan hasil sensitifitas kultur kuman atau jika belum ada hasil kultur, dipilih antibiotika yang berspektrum luas, yaitu golongan penisilin, klindamisin, atau aminoglikosida. Tujuan debridement adalah mengangkat seluruh jaringan nekrosis (devitalized tissue). ${ }^{8}$ Sebelum dilakukan debridement sebaiknya dicari sumber infeksi dari uretra atau dari kolorektal dengan melakukan uretroskopi atau proktoskopi. Kadang-kadang perlu dilakukan diversi urine melalui sistostomi atau diversi feses dengan melakukan kolostomi. Setelah nekrotomi, dilakukan perawatan terbuka dan kalau perlu pemasangan pipa drainase. Setelah 12 dan 24 jam lagi dilakukan evaluasi untuk menilai demarkasi jaringan nekrosis dan kalau perlu dilakukan operasi ulang. Debridement yang kurang sempurna seringkali membutuhkan operasi ulang bahkan dilaporkan dapat terjadi dua atau empat kali harus masuk kamar operasi. Pemberian oksigen hiperbarik masih kontroversi. Terapi ini bermanfaat pada infeksi kuman anerobik. Perawatan luka pasca operasi dengan hidroterapi dengan kombinasi rendam duduk hangat, dan pemberian hidrogen peroksida. Pemberian madu yang belum diproses berguna dalam membersihkan 
jaringan nekrosis secara enzimatik, mengurangi bau, mampu mensterilkan luka, menyerap air dari luka, memperbaiki oksigenasi jaringan, dan memingkatkan reepitelialisasi. Pada beberapa tahun terakhir ini dikembangkan metode Negative Pressure Wound Care untuk melakukan perawatan luka pada pasien dengan Fournier's Gangrene sebelum dilakukan debridement dan digunakan sebagai metode untuk menurunkan nyeri dan meningkatkan kenyamanan klien. ${ }^{15}$

\section{METODE}

Strategi pencarian studi berbahasa Inggris yang relevan dengan topik yang telah ditentukan sebelumnya, dilakukan dengan mengakses database PubMed, ScienceDirect, dan SAGEPub dibatasi dari Januari 2004 sampai dengan Oktober 2013. Keyword yang digunakan adalah "Fournier's gangrene", "negative pressure wound therapy", "Vacuum-assisted closure", "chronic wound therapy”. Artikel fulltext dan abstrak direview, untuk memilih studi yang sesuai dengan criteria. Kriteria inklusi dalam review adalah berbagai penelitian yang menunjukkan penggunaan negative pressure wound therapy pada fournier's gangrene, evaluasi terapi dan faktor yang mendukung maupun menghambat efektifitas negative pressure wound therapy. Hasil pencarian tersebut ditemukan 42 artikel, setelah dilakukan analisis sederhana terhadap judul dan abstrak hanya empat artikel yang sesuai dengan kriteria inklusi berupa dua randomized control trial dan dua case report.

\section{PEMBAHASAN}

Fokus perawatan pada teori comfort ini pada intinya adalah perawat mengidentifikasi kebutuhan kenyamanan yang tidak terpenuhi dari pasien, sehingga berdasar pengkajian tersebut kemudian menentukan desain tindakan comfort untuk mengatasi serta menggali hal-hal yang dapat meningkatkan kenyamanan pasien yang mana hal ini merupakan outcome langsung dari tindakan keperawatan. ${ }^{14}$

Negative Pressure Wound Therapy merupakan salah satu metode perawatan luka yang berdasarkan berdasarkan aplikasi tekanan subatmosfir. Metode ini telah berhasil digunakan dalam perawatan luka yang rumit misalnya luka bakar derajat yang luas, luka infeksi, kondisi luka dengan sirkulasi yang buruk, luka terbuka dan luka yang mengalami gangguan proses penyembuhan luka.

Negative Pressure Wound Therapy meningkatkan proses penyembuhan luka dengan cara meningkatkan laju angiogenesis, meningkatkan proliferasi endotel, meningkatkan integritas membran basal kapiler, aliran darah kapiler, serta mengurangi edema interstitial dan mengurangi kolonisasi bakteri dalam luka. ${ }^{15}$

Negative Pressure Wound Therapy terdiri dari foam dressing yang terhubung ke tabung evakuasi. Sebuah unit untuk memberikan negatif tekanan diterapkan ke ujung lain dari tabung evakuasi.

Foam dressing ini terdiri dari foam yang terbuat dari open-pori dari poliuretan eter atau polivinil alkohol. Adanya pori-pori di foam dressing ini memungkinkan sistem sel terbuka untuk menciptakan pemerataan tekanan negatif topikal ke seluruh luka. Evakuasi tabung tertanam dalam busa dan ditempatkan sejajar dengan luka, untuk mengabsorbi cairan ataupun nanah yang diproduksi oleh luka. Tekanan yang diatur sesuai dengan kedalaman, luas dan produksi darah/serumen. Tekanan yang dianjurkan mulai 50 hingga $125 \mathrm{mmHg}$ dan dilakukan evaluasi tekanan secara berkala. ${ }^{6}$ Negative Pressure Wound Therapy dapat mempercepat penyembuhan luka dengan cara:

1. Mempertahankan lingkungan yang lembab

2. Menghapus eksudat luka

3. Meningkatkan local aliran darah

4. Meningkatkan pembentukan jaringan granulasi

5. Menerapkan tekanan mekanis untuk mempromosikan luka penutupan

6. Mengurangi beban bakteri pada luka.

7. Dressing oklusif mempertahankan lingkungan yang lembab, yang bermanfaat untuk penyembuhan luka.

Terdapat kontraindikasi penggunaan dari negative pressure wound therapy yaitu: jaringan nekrotik luas, keganasan, dyscrasias darah/gangguan koagulopati, fistula, sepsis, dan open body cavities. ${ }^{1}$ Namun cara ini lebih efektif dari perawatan secara konvensional pada penderita Fournier's gangrene. Efektivitas dari perawatan luka dengan Negative Pressure Wound Therapy ditentukan dengan melihat hasil utama dari peningkatan penyembuhan luka, hal ini dapat dievaluasi dengan kejadian penutupan luka lengkap, 
penutupan luka dipercepat, fasilitasi penutupan bedah, atau meningkatkan kualitas menyembuhkan dari luka. Selain itu bisa juga dilihat dari evaluasi penurunan insiden infeksi pada luka, debris luka, penurunan nyeri yang dirasakan pasien serta kualitas hidup pasien meningkat.

\section{KESIMPULAN}

1. Negative pressure wound therapy sangat efektif untuk mengontrol drainage luka setelah debridement, mempermudah granulasi luka dan menurunkan penggunaan kasa/dressing luka dan proses perawatan dapat menimbulkan rasa nyaman bagi klien dibandingkan perawatan lain.

2. Negative pressure wound therapy merupakan aplikasi tindakan keperawatan yang berdasarkan teori Comfort yaitu meningkatkan kenyamanan klien dengan menurunkan tingkat nyeri yang dirasakan klien sehingga meningkatkan kualitas hidup klien.

\section{KEPUSTAKAAN}

1. Cipolla, et al. 2008. Negative Pressure Wound Therapy: Unusual and Innovative Application. OPUS 12 Scientist. 2:3: 1529

2. Koukouras D, et al. 2011. Fournier's gangrene, a urologic and surgical emergency: presentation of a multiinstitutional experience with 45 cases. Urol Int. 86(2):167-172.

3. Mallikarjuna, et all. 2012. Fournier's Gangrene: Current Practices. ISRN Surgery 9:42-50

4. Moisidis E, et all. 2004. A prospective, blinded, randomized controlled trial of topical negative pressure use in skin grafting. Plast Reconstr Surg;114:917922

5. Park, Ki Rin, et all. 2012. Single-Stage Reconstruction of Extensive Defect after Fournier's Gangrene with an Exposed Iliac Crest and Testes. Archieves of Plastic Surgery. 40:1:74-76

6. Pastore, et all. 2013. A Multistep approach to manage Fournier's Gangrene in a Patient With Unknow Type II Diabetes: Surgery, Hyperbaric oxygen and VacuumAssizted Closure Therapy: A case report. Journal of Medical Case Report. 7:1

7. Pelham FR, et all. 2006. Topical negative pressure in the treatment of infected wounds with exposed orthopaedic implants. J Wound Care. 15:111-116.

8. Roje Z, et all. 2011. Necrotizing fasciitis: literature review of contemporary strategies for diagnosing and management with three case reports: torso, abdominal wall, upper and lower limbs. World J Emerg Surg, 6(1):46.

9. Safioleas M, et all. 2006. A: Fournier's gangrene: exists and it is still lethal. Int Urol Nephrol 2006, 38(3-4):653-657.

10. Sehmi S, Osaghae S. 2011. Type II diabetes mellitus: new presentation manifesting as Fournier's gangrene. JRSM Short Rep, 2(6):51.

11. Shirakawa \& Isseroff. 2005. Topical Negatif Pressure Devices: Use for Enhancement of Healing Chronic Wound. Arch Dermatol. 141: 13-21

12. Sorensen MD, et all. 2009. Fournier's gangrene: population epidemiology and outcomes. Journal Urology. 181:21202126.

13. Stawicki SP, Grossman M. 2007. "Stretching" negative pressure wound therapy: can dressing change interval be extended in patients with open abdomens. Ostomy Wound Manage. 53:26-29

14. Tomey, A.M., \& Alligood, M.R. 2006. Nursing Theorists and their Work, 4th Edition. St.Louis: Mosby

15. Zagli G, et all. 2011. Treatment of Fournier's gangrene with combination of vacuum-assisted closure therapy, hyperbaric oxygen therapy, and protective colostomy. Case Rep Anesthesiol :430983. 